Hrubinko A.

Great Britain in the process of establishing Common Foreign and Security Policy of the European Union

DOI:

UDC 94(477+420):327.061

Andrii Hrubinko,

Doctor of Historical Sciences,

Professor of Department of Theory

and History of State and Law,

Ternopil National Economic University

ORCID: http://orcid.org/0000-0002-4856-5831

\title{
GREAT BRITAIN IN THE PROCESS OF ESTABLISHING COMMON FOREIGN AND SECURITY POLICY OF THE EUROPEAN UNION
}

The article presents the results of the research position and role of the United Kingdom in the process of formation of the Common Foreign and Security Policy (CFSP) of the European Union at different periods of its development. There were considered the historical peculiarities of the East European policy of Great Britain, formation of its position on Ukraine's European integration in the context of implementation of the CFSP and enlargement of the EU. The main conclusion is that Britain has neglected the EU leadership capabilities in the CFSP, which was objectively the optimal option to maximize the identification of its leadership ambitions in the Union. In the case of total withdrawal from the EU, the UK will be forced to abandon the CSDP. For the EU, Brexit can have both positive and negative consequences. Brexit will lead to a partial loss of its influence on regional processes and will have some negative consequences for the international positions of Ukraine.

Keywords: Great Britain, European Union, Common Foreign and Security Policy, Brexit, Ukraine.

\section{Грубінко А.}

Великобританія у процесі становлення зовнішньої і безпекової політики Свропейського Союзу

Представлено результати дослідження позииї і ролі Великобританії у процесі формування механізмів зовнішньої політики і політики безпеки Свропейського Союзу у різні періоди їх становлення і розвитку. Розглянуто історичні особливості східноєвропейської політики Великобританії, формування ї̈ позиції щзодо євроінтеграції України в контексті реалізації СЗБП і розширення СС. Проаналізовано особливості британського підходу до формування Спільної політики безпеки та оборони СС з огляду на відносини СС - НАТО. Зазначено, щзо Великобританія пройшла оригінальний історичний илях участі в євроінтеграційних процесах, намагаючись адаптувати їх до своїх державних потреб та міжнародних інтересів. Керівництво держави намагалося використовувати механізми об'єднання для посилення свого впливу на міжнародній арені, але дотримувалося мінімалістичних позицій щодо їх розвитку. 3 ичією метою існував ряд внутрішніх $і$ зовнішніх детермінантів, які можна було б звести до єдиного иентрального чинника: уряди Великобританії не вважали європейську інтеграиію пріоритетним напрямком у фокусуванні свойх міжнародних зусиль, щчо могли б замінити важливість інших історично важливиї зовнішньополітичних пріоритети (відносини зі США та державами Співдружності Націй). Тому СЗПБ ЄС розглядався як важливий, але не головний механізм зовнішньої політики королівства. Основним висновком дослідження є те, щзо Великобританія нехтувала лідерськими можливостями ЄС у сфері СЗБП, щзо об 'єктивно було оптимальним варіантом для максимального виявлення своїх лідерських амбіційю. Внаслідок повного виходу з СС Великобританія буде змушена покинути механізми СЗБП. Це завдасть суттєвого удару по історичних амбіціях королівства щуодо відродження його ролі як світової держави та може коштувати ії цілісності, враховуючи проблему проєвропейської Шотландії. Вихід королівства з СС ліквідує усталений баланс сил в середині об'єднання. Одним з наслідків «Вrехіт» може стати посилення відиентрових тенденцій в об'єднанні і послаблення його впливу у світовій політиці.

Ключові слова: Великобританія, Європейський Союз, Спільна зовнішня і безпекова політика, «Breхіt», Україна.

Formulation of the problem. The process of the country's exit from the EU (unofficial called as «Brexit»), which was the result of the national referendum on 23 June 2016, is a catalyst not only for British public confidence in European integration, the country's relations with regional partners and institutions, but also the Union that is experiencing the most profound and complex crisis in its history. That's why it is therefore important to analyze the historical experience and peculiarities of the UK's participation in the CFSP with a projection of the possible consequences of Brexit for the international position of the country and the EU in a modern globalized and poorly predicted world.

(c) Andrii Hrubinko, 2019 
The formation of the foreign policy, dimension of EU's security and the contribution of Great Britain to this process is relevant for the study in view of the need to know the origins and causes of modern complex transformations of the regional and world system of international relations, the emergence of new threats to international security, in the epicenter of which was Ukraine. The experience of British participation in European integration can become instructive for Ukraine in its desire to become a full participant in regional integration processes.

Analysis of recent research and publications. The analysis of European and American historiography shows that the researchers are paying considerable attention to the subject of European integration and participation Great Britain in general, which can't be said about the study of the issue of the participation of this country in the CFSP of the EU. The group of British researchers in the history of the formation and development of the CFSP represents the publications of F. Cameron, Ch. Grant, J. Howorth, on pages of which this issue has found a certain amount of coverage. Researchers M. Oakes, A. Forster, T. Valasek payed their attention to the research of the development of European defense cooperation and the role of the UK in establishment of the Common Security and Defense Policy (CSDP) of the EU. Researchers R. Balfour, I. Bond, S. Bench, etc. provides an analysis of the implications of the UK's exit from the EU for the CFSP. Among the Ukrainian scientists, we will highlight publications on the history of membership of Great Britain in the EU of Britannists A. Hrubinko, Y. Krushynskyi, N. Yakovenko. In the Russian historiography some attention to studying of the contribution of Great Britain to the development of the CFSP in separate parts of their works was paid T. Andreeva, A. Morozov, S. Ochkanov, A. Valuev, A. Gromyko. In Ukrainian and Russian historiography the problem of involvement of Great Britain in the CFSP of the EU is not sufficiently developed.

The aim of the research position and role of the United Kingdom in the process of formation of the CFSP of the European Union at different periods of its development.

Main results of the research. The European Union has historically become a combination of two different types of international cooperation - an international organization and an intergovernmental association on the basis of founding treaties. This is especially noticeable in the field of foreign and security policy. The main distinctive feature of the CFSP is the strong dependence of the process of its development and implementation on the interests of the states-subjects. The CFSP expertise according to the Maastricht Treaty of 1992 includes all issues of international relations, in particular, the protection of international peace and security, the gradual formation of a common defense policy, the provision of the interests of the EU as an international actor in relations with third countries and international organizations [1]. So, the CFSP can be defined as a special subsystem of multi-level interaction between states and supranational institutions in the field of the formation, organization and implementation of representation the Unity on the international scene, relations between Member States and institutions with third countries, international organizations and non-state structures that include diplomatic relations, military-political cooperation and defense cooperation, development of projects military-technical cooperation, joint military-civilian peacekeeping operations outside the Union. The EU's security policy combines the classical elements of military cooperation between Member States (with the participation of Union institutions) and elements of its more natural humanitarian impact on the environment. This allowed the leadership of Britain to use the potentially wide opportunities for unification in the international arena, while maintaining loyalty to the traditional guidelines of the state's foreign policy.

In the process of research scientific problem it's necessary to take into account three fundamental aspects that define the UK's policy line in partner relations: 1) mentioned specificity of this straightforward the EU's policy; 2) the foreign policy of the state is always dependent on and complementary to the internal one, which is especially relevant in the case of the United Kingdom and its established approaches to European integration (Euro-skepticism); 3) Britain in its foreign policy is traditionally closely associated with the United States, which adds to the country the political and military-strategic importance in Europe. Therefore, in the historiography, the assertion about the presence of the dichotomy of the strategic directions of British foreign policy at the EU-US level is widespread [2, p. 1315-1316]. The specified characteristics of the CFSP, the validity of the established principles and guidelines of foreign policy have contributed to the controversial nature of Britain's involvement in this area of association.

The preconditions for the formation of the foreign policy component of the European Union arose from the post-war attempts to establish a regional political and defense community (1952), the introduction of a mechanism of European Political Cooperation (EPC) in the early 1970's. The British elite saw the EPC as an additional resource to implement the international interests of the state, the opportunity to show their leadership in European politics, strengthen its influence in relations with the US and the USSR, reduce the influence of France and Ger- 
Hrubinko A.

Great Britain in the process of establishing Common Foreign and Security Policy of the European Union

many, to compensate the limited participation in the areas of classical integration. The fidelity to the concept of Atlanticism and, at the same time, the need for active engaging in the processes of regional union has led to the dichotomy of its foreign policy between the EEC/EU and the United States (NATO). The effectiveness of such a policy has not called into question the end of the Cold War. However, changes in the system of international relations of the 1990's put the choice of both the EU and Great Britain - to maintain the status quo in the European security system or to formulate their own international policies backed up by new regional resources.

British political strategy for relations with continental Europe in the second half of XX century evolved from distancing to direct participation in regional integration associations, coupled with an attempt to adapt the development processes of the European Community to their interests. The United Kingdom's membership in the EEC in 1973 was a necessary step aimed at strengthening of the international position of the state in the conditions of absence of any other Community alternative. For British society, European integration was expedient in terms of effective management and was not considered historically inevitable [3]. Despite the positive consensus reached in the British policy regarding the involvement of the kingdom in the foreign policy cooperation of the EEC, this issue did not find significant reviews in the masses, and was supported mostly by the political and business elite, part of the diplomats of new generation. The Euro-skeptical British press has been the constraining factor for spreading the objective information about the EEC.

The limited institutional and functional status of the EPC, its absence in the legal (contractual) field of the EEC, the withdrawal of security issues beyond their competence set the British political elite. The decisions within the framework of the EPC were of a recommendatory nature. At the same time, the attempts of the British leadership to play a leading role in the political cooperation of the EEC countries had contradictory results that were inherent in the participation of the kingdom in European integration as a whole. In opposition to the British government, the autonomy of the European military organization contradicted the further cooperation of the states of the region in the field of security and defense. The tendency of limiting the European policy of official London to a tolerance of Atlanticism has become firmly established. In the end, Margaret Thatcher signed the Single European Act of 1986, which for the first time introduced the EPC mechanism into the legal field of the EEC. In the matter of military-political cooperation of the EEC, the conservative government was in positions of «Atlantic» Euro-skepticism. The reached level of the arrangements was considered by official London as the final stage of the formation of the European association. The confrontation of the British government with the autonomy of the European military organization contradicted the further cooperation of the states of the region in the field of security.

During the existence of the EU the UK's governments have been pursuing a strategic line to curb the autonomy of European foreign policy and security in order to keep them under the traditional approaches of interstate cooperation (and not integration) and Atlantic solidarity. At the same time, the main tactical tool of British politics remained active in discussing strategic issues of the CFSP and periodic support for certain innovative initiatives. The purpose is to intercept the strategic initiative of the federalist «core» - Germany and France, to control the process of building political integration from the middle to maintain the status quo in the transatlantic security system.

The Government of the prime minister John Major supported the Franco-German initiative to establish a CFSP to the «second pillar» of the European Communities. Conservatives tried to maintain traditional approaches to international politics and European security. Therefore, the first period of the kingdom's participation in the CFSP (1990-1997) can be defined as traditionalist. During the preparation of the Treaty on European Union, the conservative government tried to reduce the formation of the CFSP to a level of intergovernmental cooperation. If the British agreed to meet the requirements of EU's foreign policy, their interpretation of the CSDP as a «European pillar» of NATO was different from the perspective of the supporters of EU's autonomy on the question of security. The London's bet on the WEU, as a military resistance to the EU, has forced the negotiators to postpone the issue of providing a united military dimension [4, p. 17]. The abstract formation of the treaty in the part of the CFSP satisfied the kingdom's interests.

Britain's agreement to establish the CFSP was due to international circumstances and the need to affirm its own borrowing within the EU, rather than a conscious strategic choice of political elites. In London, they sought to restrict the EU's competence in the area of foreign policy and security in according to the Atlantic interests and integrity of state sovereignty, although generally welcomed the cooperation of the member states of the Union. The pragmatic nature of the motives of the country's participation in the European integration system has been shown by John Major in a speech at the conference of the European Democrats on 12 September 1991 [5].

The breakthrough in the development of the CFSP was due to the pro-European position of the government of Prime Minister Tony Blair, who renewed the long-standing idea of British leadership in Europe and 
pursued a policy of pragmatic Euro-optimism. In general, policy of the Labor Government (1997-2007) in the European direction has confirmed the preservation of the inviolability of the strategic priorities of foreign policy. Pro-European rhetoric skillfully presented in the first years of activity, backed by spectacular political decisions aimed at convergence of positions with European partners, showed an increase in flexibility of the position of the British establishment in making tactical decisions in the face of changing European imperatives. Among them, the signing of the Amsterdam Treaty, which for the first time formed the institutional mechanisms of the CFSP, the historic Franco-British Declaration of Saint-Malo in 1998 on the development of autonomous NATO-led military structures and units within the CSDP, the agreement on the transfer of key functions from the WEU to the EU, active support for enlargement the European Union. The signing of the Saint-Malo Declaration was the beginning of the evolutionary and progressive period of the Kingdom's participation in the CFSP (1998-2002). According to European researchers, the Saint-Malo Declaration has become a reference point for the real development of European security capabilities [6, p. 1]. However, the policy of the second and third government of Tony Blair's government (2001-2007) showed that the deepening of the country's participation in the integration processes was largely declarative. At the stage of developing the Nice Treaty, the previous initiative and progressive attitude of the British Government towards the development of the CFSP have been significantly reduced. During a speech in Warsaw on 6 October 2000, Tony Blair stated that the Union as a unique combination of intergovernmental and supranational may become «supergovernment, but not a superstate» [7].

During the period of the adoption of the Constitutional Treaty, the role of Great Britain in the development of European political integration was also ambiguous. The government has continued to actively support the formation of EU's foreign and military mechanisms. However, the unilateral decision on Britain's participation in the war on Iraq in 2003 as a consequence of the traditional following of international ambitions of the US led to the situation which paralyzed the CFSP and questioned the country's leadership in Europe. The British leadership failed to achieve a balance between European and Atlantic foreign policy. Charles Grant stated that Tony Blair lost the status of «European leader» [8]. The failed attempts by France and Germany to introduce a model for deep integration in the security sector have shown that it is impossible to develop of CSDP without the United Kingdom.

The active role of Great Britain in European politics after the 2003 intervention in Iraq marked the beginning of a new period in the history of state participation in the CFSP, which can be characterized as realistic or pragmatic-functional (2004-2010). The state leadership during the «constitutional process» chose moderatelyconstructive tactics, agreeing on the overall insignificant centralization of the CFSP. Blair's government made concessions regarding the introduction of the posts of the President of European Council and the Union Foreign Minister, the diplomatic service of the Union (European External Action Service), the extension of the vote in the EU Council by qualified majority and the mechanism for in-depth cooperation on security and defense. In London, they supported the adoption of the European Security Strategy, but opposed the creation of a joint headquarters of the EU forces and the strengthening of European institutions for the sake of the Atlantic interests. Providing the legal personality of the European Union allowed the association to become a full-fledged independent subject of international law. At the same time, the decisive role of parliaments in foreign and defense policy is preserved. Tony Blair called the new treaty a success for the UK [9, p. 1081].

As a result of the unsuccessful ratification of the EU Constitutional Treaty in France and the Netherlands on May 29 and June 1, 2005, the British Government, accordingly, avoided the expected role of the most problematic member of ratification. The failure of the treaty did not affect the continuation of London's implementation of the CFSP programs and projects. However, the loss of Labor's popularity and the fall of the international image of Tony Blair personally after the Iraqi campaign led to an increase in Euro-skepticism.

The European policy of the Labor government under the leading of the prime minister Gordon Brown (2007-2010) broadly followed the pragmatic line of predecessors, and its biggest achievement was the signing of the Lisbon Treaty of the EU on 13 December 2007. The prime minister managed to preserve the special status of Britain in the EU and to defend a number of fundamental positions in preserving the main principles of the functioning of the CFSP. In particular, at the insistence of London, the project was removed from the project by the EU foreign minister. Brown's regional government policy became more pragmatic. The CFSP was not given the proper attention. At the same time, the appointment of Baroness Catherine Ashton, the High Representative for Foreign and Security Policy of the EU became significant for the UK development of the CFSP. British diplomats led by Richard Cooper, former adviser of the Prime Minister Tony Blair, became active creators of the European External Action Service.

The governments of Conservatives leading by David Cameron (2010-2015, 2015-2016) can be characterized as skeptical-inertial to participate in the CFSP and in general, the membership of the state in the 
Hrubinko A.

Great Britain in the process of establishing Common Foreign and Security Policy of the European Union

Union. The European policy of the British governments was characterized by special skepticism, isolationism and the complexity of dialogue with European partners. Ratification of the Lisbon Treaty was assessed as a betrayal of the country's democratic traditions [10, p. 113-114). The ruling party proclaimed an aggressive course to revise the regulatory framework and the role of Britain in the Union's structure. The country was again in the role of the main opponent of the deepening of European integration. The level of state participation in the CFSP was significantly reduced. At the same time there was a functional paradox. The British government remained an active participant in the process of shaping the EU's international position and often spoke on its behalf in the international arena, allocating the largest budget allocations to European defense. Almost no humanitarian mission or peacekeeping operation of the EU was conducted without the participation of British specialists. At the same time, one of the areas of expedient reduction of communitarian expenditures in London was precisely the CFSP.

In the area of security and defense, the British position was unchanged - the EU's resources should complement NATO and not replace national defense capabilities. David Cameron's Cabinet raised the issue of the expediency of funding the European Defense Agency and vetoed the creation of a permanent EU Operational Headquarters [11, p. 1306]. London refused to allocate military units to the Eurocorps, to join a number of the EU's infrastructure projects. The government of the prime minister David Cameron has violated the established dichotomy of «Europeanism»»Atlanticism» in the foreign policy of the state. The kingdom, thanks to the victory of Euro-skeptic populism, lost its chance for leadership in a united Europe. David Cameron's office implemented a strategy of in-depth cooperation at the traditional bilateral intergovernmental level, primarily within the framework of British-French military-political cooperation. In response to the proposals made by the European Commission on the development of CSDP, approved by the European Council on 20 December 2013, David Cameron said that London would block initiatives to create a European army, calling them «the fantasies» [12]. He made it clear that it was not necessary to rely on the active position of the UK in development of European defense structures. The National Security and Defense Strategy of the UK in 2015 does not foresee further involvement of the Royal Armed Forces in the EU's military operations [13, p. 53].

David Cameron retained the belief in the possibility of reforming the EU in accordance with the British model of the «Common Market». During talks with the leadership of EU institutions and member states during November 2015 - February 2016, David Cameron did not demand revision of the terms of state participation in the CFSP, but rejected the deepening of political integration in general. The British side sought at least to preserve the current level of state participation in the Community. Although the prime minister before that event called on citizens to vote for Britain's membership in the European Union, most participants (almost 52\%) on 23 June 2016 did not support his position. David Cameron entered the history of the UK as a prime minister, who destroyed the balance of relations between the UK and European Community, which existed since 1973.

London continued its previous line to defend its own interests, trying to block the disadvantageous political processes. This was evidenced by the negative reaction of British side to the call of European colleagues to develop a common strategy for further relations with the USA after Donald Trump won the presidential election in 2016. As it was expected, the reaction of the British Government to the appeals of the High Representative for Foreign Affairs and Security Federica Mogherini to development of cooperation in the field of the CSDP, in particular, the next attempt to create a permanent Operational Headquarters of the EU's armed forces, was negative $[14$, p. 6]. Its creation was blocked by the British side traditionally.

The European policy of the British government under the leading of the Prime Minister David Cameron did not contribute to the strengthening of European defense identity. London frankly favored the formation of the NATO Response Force. The primacy of the Atlantic commitments was certified by David Cameron when signing military cooperation agreements with France in November 2010. The parties undertook to promote closer cooperation between NATO and the EU [15]. During the March-October 2011 military campaign in Libya, the British government vetoed the French proposals to transfer the EU forces to operational action and the creation of the European Command Operations Center, giving preference to the NATO's Headquarters [16, p. 254].

Atlanticism's primacy in British foreign policy was immediately manifested in the crisis of international relations in connection with Russia's military aggression against Ukraine. Russian aggression has shown the need to change the European policy of the United States and NATO, their return to the European concentration zone. There was a shift in emphasis in NATO's policy on the defense of the Central-Eastern European region, as recorded in the summit decisions in Newport (Wales) on 4-5 September 2014. In the National Security and Defense Strategy of the United Kingdom 2015 in the system of key partners of the state in the Euro-Atlantic area the EU is indicative latter after NATO, the United States, France, Germany and others [13, p. 53]. As a result of Britain's withdrawal from the EU, the strengthening of its military machinery is not ruled out. This is supported by the French government, which carries out systematic work on the development of a European regional defense 
system, autonomous from US resources, in the hope of forming a European Defense Union [17]. At the same time, Brexit can complicate the process of European unification in the security sector without the presence of British resources, to weaken the difficult relations between the EU and NATO.

Great Britain has made a significant contribution to the formation and implementation of operational security activities of the European Union. Since 2003, the United Kingdom at various levels of representation has participated in virtually all EU military operations and civilian missions in the regions of the Balkans, the Middle East, Africa, the post-Soviet space. London was one of the largest donors of EU operations and missions. The kingdom has participated in most of the operational peacekeeping operations of the association, becoming one of the major donors in the system. The withdrawal of the state from the EU in 2020 and the possible refusal of Britain to participate in militarycivilian operations and EU missions will weaken the operational security potential of the association, but in the long run may enable it to carry out international activities more independently from NATO [18].

The British governments have been active in promoting a number of Central Eastern Europe states on their path to EU membership. Integration of the Central Eastern Europe (CEE) region countries into the EU has become one of the main successes of the British governments in the process of developing of the CFSP. The British government, while looking for the political benefits of continuing the enlargement of the EU, did not forget its domestic interests. Contrary to the commitment of the concept of «expansion instead of deepening», The kingdom's government shown their solidarity with the representatives of other «big» EU's states (France and Germany) in the distribution of budgetary funds of the association, places in its institutions, and since the second half of the 2000's established restrictions on migration flows from the new states-members and candidates. In general, the British government's policy on eastern enlargement of the EU defined a pragmatic political calculation. The decline in the support of the policy of enlargement and its greater pragmatism was inherent in the governments of the conservative Prime Ministers David Cameron, Theresa May and Boris Jonson, which, along with confrontational relations with the EU, has reduced the influence of the state in the region. London recognized the need for a strategic pause in expansion.

Eastern European politics of Great Britain was formed in the general context of development of relations of the states of the Western Europe and the USA with the countries of the post-Soviet space. London's policy on them developed in line with the general policy of the West in the post-Soviet space. Only in the early 2000's the EU introduced a separate comprehensive program of cooperation with the states of the region - the European Neighborhood Policy (subsequently the «Eastern Partnership» was singled out), with the British government as the co-author. Position of the kingdom in relation to the countries of Eastern Europe varied according to the needs of a compromise with the partners in the unification and dynamics of relations with Russia. London adhered to the position of recognizing the possibility of Eastern European membership in the European Union in the long run. In general, the Eastern European policy of the EU and Britain remained a peripheral component of the CFSP. Only the Russian-Ukrainian conflict has turned London's attention to the problems of this region.

Britain's policy towards Ukraine depended on the positions of the United States and Russia. Nuclear disarmament, Russian-Ukrainian territorial contradictions, unwillingness of the British elite to perceive Ukraine outside the context of the Russian factor formed the main factors of its perception in Europe and in the world. At the same time, informed government circles were aware of Ukraine's weighty role for European security [19, p. 3]. The UK supported the European integration course of Ukraine, but wasn't in hurry to provide the significant assistance and to consider relations with Kiev beyond the Russian factor. Britain government to the events of 2014 did not consider Ukraine as the main strategic state for ensuring security in the CEE region. The impairment of the image of Ukraine's leadership in the international arena as a result of scandals surrounding the murder of journalist Georgii Gongadze, the sale of weapons to Iraq, oppression of political opposition against the background of traditional problems of state development (corruption, authoritarian power, curtailment of reforms, economic problems) determined the context of relations between Ukraine, the EU and the United Kingdom in 2001-2004. The British Neighborhood Initiative in 2002 did not foresee the prospective of membership in the EU or even the association of Ukraine. Only the events of the «orange revolution» somewhat improved the image of Ukraine in the British public opinion. The official position of the United Kingdom at the stage of adopting the Eastern Partnership program was to support the deepening of Ukraine's relations with the EU without answering the question of its membership. In London, in turn, they decided to compromise with the EU partners (France and Germany). At the same time, an argument for Britain's support for Euro-Atlantic integration of Ukraine was the Russian-Georgian armed conflict in August 2008 [20 p. 3]. Britain supported the signing of the Association Agreement between Ukraine and the EU in 2014. In the context of the Russian-Ukrainian conflict, the British government acted as an active supporter of the adoption of a political decision by the EU on the introduction of anti-Russian sanctions and the provision of assistance to Ukraine. Brexit will weaken Ukraine's position in relations with the European 
Hrubinko A.

Great Britain in the process of establishing Common Foreign and Security Policy of the European Union

Union and will strengthen pro-Russian tendencies among its member states. In the context of the Brexit, the UK's strategic importance for Ukraine in its integration into the European integration process will be reduced.

Conclusions. Great Britain has passed original historic way of participating in European integration processes, trying to adapt them to their state needs and international interests. Such a strategy became particularly noticeable in the CFSP. The state leadership tried to use the mechanisms of membership to strengthen its influence on the international arena, but adhered to minimalist positions regarding their development. The British governments did not consider European integration as a priority area in the focusing of their international efforts. Therefore, the CFSP of the European Union was seen as an important but not the main mechanism of the foreign policy of the kingdom. The Atlantic and pro-American positions of the United Kingdom have become one of the decisive and at the same time contradictory factors for the establishment of the CSDP.

As a result of the total withdrawal from the EU, the United Kingdom will be forced to abandon the CSDP. It will strike a significant blow to the historical ambitions of the UK to revive its role as a world power, weaken its influence on regional processes. Brexit can cost the country a stability on the internal and external levels. For the EU, Brexit can have both positive and negative consequences. Without Britain in the EU, there is a greater chance of forming a more united and effective military organization. At the same time, the diplomatic and military structures of the EU, the CSDP system in general, will lose skilled British specialists and a significant part of the resources. Brexit eliminates the established balance of power in the Union. One of the consequences of Brexit may be the strengthening of centrifugal tendencies in uniting and weakening its influence in world politics.

Consequently, the history of Britain's participation in the CFSP in the context of the Brexit process shows that Britain has never been able to find its place in the European Union. The history of its membership in the EU provides an instructive experience of a complex process of building relations with the institutions and partners in the Unity, which should be taken into account in Ukraine. Brexit lead to a loss of its influence on regional processes and will have some negative consequences for the international positions of Ukraine.

\section{References}

1. European Union, (1992). Treaty on European Union. Official Journal of the European Union, C 191, 00010110 [in English].

2. Cyr, A. (2012). Britain, Europe and the United States: change and continuity. International Affairs, No 88(6), 1315-1330 [in English].

3. George, S. (1995). Britain and European Integration since 1945. Oxford-Cambridge [in English].

4. Hewitson, M. (2012). The United States of Europe: The European Question in the 1920s. Europe in crisis. Intellectuals and the European Idea, 1917-1957. Chapter 1, New York, Oxford, 15-34 [in English].

5. Mr Major's Speech to European Democratic Union Conference. Below is the transcript of Mr Major's speech to the European Democratic Union Conservative Party Leaders' Conference, given on Thursday, 12 September 1991. The Rt Hon Sir John Major KG CH - Prime Minister of Great Britain and Northen Ireland 19901997. Retrieved from: http://www.johnmajor.co.uk/page950 [in English].

6. Howorth, J. (2003). Saint-Malo plus five: an interim assessment of ESDP. Notre Europe. Policy papers, 7, 36 [in English].

7. British Prime Minister Tony Blair's speech to the Polish Stock Exchange in Warsaw. 6 October 2000. EU Observer. 29 May 2001. Retrieved from: https:/euobserver.com/news/2450 [in English].

8. Grant, Ch. (2003). Blair's five wars. Prospect Magazine. Retrieved from: http://www.prospectmagazine. co.uk/magazine/blairsfivewars [in English].

9. Commons Sitting of 21 June 2004. European Council. Hansard-House of Commons debates. House of Commons Historic Hansard for debates from 1803-2005, HC Deb 21 June 2004, 6 (22). 1079-1096 [in English].

10. The Conservative Manifesto 2010, (2010). London: Conservative Party.

11. Biscop, S. (2012). The UK and European defense: leading or leaving. International Affairs, 88(6), 1297-1313 [in English].

12. European Council December 2013: David Cameron's press conference. Prime Minister's Office, 10 Downing Street and The Rt Hon David Cameron MP. 20 December 2013. Brussels. Retrieved from: https://www.gov. uk/government/speeches/european-council-december-2013-david-camerons-press-conference [in English].

13. National Security Strategy and Strategic Defense and Security Review 2015. A Secure and Prosperous United Kingdom, November 2015. London: HM Government [in English].

14. Bond, I., Besch, S., Gostyńska-Jakubowska, A., Korteweg, R., Mortera-Martinez, C., Tilford, S.(2016). Europe after Brexit Unleashed or undone? London: Center for European Reform [in English]. 
15. Operations in Libya, (2012). Ninth Report of Session 2010-12. House of Commons. Defense Committee, Volume I: Report, together with formal minutes, oral and written evidence. London [in English].

16. UK-France Summit 2010 Declaration on Defence and Security Co-operation. Tuesday, 2 November 2010. Retrieved from: https:/www.gov.uk/government/ news/uk-france-summit-2010-declaration-on-defence-andsecurity-co-operation [in English].

17. European defense coalition launched in Paris. Reuters. November 7, 2018. Retrieved from: https://www. reuters.com/article/us-europe-defence/european-defense-coalition-launched-in-paris-idUSKCN1NC291?il=0 [in English].

18. Hrubinko A. (2017). Great Britain in the European Foreign and Security Policy system (1990-2016) [Velyka Brytaniya u Evropeiskii Zovnishnii i Bezpekovii Politutsi (1990-2016]. Ternopil [in Ukrainian].

19. About Britain's policy on Ukraine and from major international issues (political letter). December 1993. Division of the State Archives of the Ministry of Foreign Affairs of Ukraine, 110, 3 [in English].

20. Miliband, D. (2008). Ukraine, Russia and European stability. The Guardian, 29 August [in English].

Стаття надійшла до редакції 10.12.2019. 